\title{
ONLINE COURSES: PROSPECTIVE STUDENT STRUCTURE PREFERENCES AND PRECEIVED SKILLS NEEDED/POSSESSED
}

\author{
Allen D. Truell, Ball State University, atruell@bsu.edu \\ Melody Alexander, Ball State University, malexander@bsu.edu \\ Jensen Zhao, Ball State University, jzhao@bsu.edu \\ Rodney Davis, Ball State University, rdavis2@bsu.edu
}

\begin{abstract}
There is little doubt that institutions of higher learning will continue offering an ever increasing number of online courses and programs. As such, information systems faculty have a keen interest in understanding both the course structure preferences and the perceived skills needed/possessed by prospective online students. Thus, the purpose of this study was to examine the course structure preferences and the perceived needed/possessed skills of prospective online students. Results of this study provide insight for information systems faculty when developing and/or revising their respective online courses and programs.
\end{abstract}

Keywords: online programs, student skills

\section{INTRODUCTION}

There is little doubt that institutions of higher learning will continue offering an ever increasing number of online courses and programs. As the ever increasing number of online courses and programs grow, so is the interest in the factors contributing to student success in such courses and programs $[1,2,3,4,5,6,7,8,9,10$, \& 11]. For example, Harrell and Bower [5] reported that online course student persistence rates are considerably lower than are those of traditional face-to-face course student persistence rates. To help develop understanding, they conducted a study to determine what student characteristics predicted persistence in online courses. Specifically, Harrell and Bower [5] explored the impact of learning style, locus of control, computer experience and access, previous online experience, and various demographics as they are related to online student success. They reported the variable basic computer skills as important for online student course persistence.

Galy, Downey, and Johnson [3] reported that the ability to work independently was important for online student performance. As a result of their findings, they suggested that assessing the ability to work independently might be beneficial for prospective online students. Aragon and Johnson [1] found in a similar study that the variables of personal time, course design/communication, technology, and learning preferences were important for online student success.

Hung, Chou, Chen, and Own [7] conducted a study to determine online student learning readiness components. In their study, the Online Learning Readiness Scale was used to assess five dimensions: self-directed learning, motivation for learning, computer/Internet self-efficacy, learner control, and online communication self-efficacy. Hung, Chou, Chen, and Own [7] indicated that two readiness dimensions of learner control and self-directed learning might need attention. Specifically, they suggested that faculty may need to assist online students in developing self-directed learning and learner-control skills and attitudes. Levy [9] conducted a study exploring student persistence in online courses. Results of the study indicated that students early in their respective programs are more likely to not persist in online courses. Levy [9] further suggested that students with less online course experience tended to not persist more often than do experienced online students. In a similar study, Kerr, Rynearson, and Kerr [8] reported four student characteristics as important for online course success. These four student characteristics included: reading and writing skills, independent learning, and motivation, and computer literacy.

Doherty [2] conducted a study exploring student factors impacting retention in online courses. Results of the study indicated that time management and procrastination were the primary reasons why online students failed or dropped courses. Doherty [2] reported that the lack of feedback from faculty contributes to online students failing or dropping courses. In addition, it was reported that unsuccessful online students stated that flexibility was an important attribute of such courses as they were too busy to attend traditional face-to-face courses. Doherty [2] explained that candid conversations with prospective online course students about the difference between flexibility 


\section{Issues in Information Systems \\ Volume 14, Issue 1, pp.415-420, 2013}

and class expectation might be needed. The researcher postulated that students may have the mistaken impression that online courses require a lesser course time commitment. Morris, Finnegan, and $\mathrm{Wu}$ [10] conducted a study exploring online student course engagement. They found that student course completers engaged in class activities more often and in longer time lengths than did students who dropped online courses. As such, they concluded that active participation in online courses is important for student success.

\section{NEED FOR THE STUDY}

A number of researchers have called for additional study of the factors influencing student success in online courses [5, 6, 7, \& 11]. For example, Harrell and Bower [5] noted that online student course persistence is very important issue for administrators. Harrell and Bower [5] further stated that there is a lack of understanding regarding the variables influencing online student course persistence and that student persistence factors should be proactively identified. Further, Holsapple and Lee-Post [6] stated that understanding student readiness for successfully completing online courses is critical. In addition, Hung, Chou, Chen, and Own [7] expressed that understanding online student readiness is important for those managing such programs. Wojciechowski and Palmer [11] explained that online course students are characterized by having high dropout/failure rates. As such, they noted that it is in the interest of prospective online course students and program administrators to understand the characteristics of successful online course students. Thus, this study will add to the important and growing literature base examining factors related on online course student success for information systems faculty.

\section{PURPOSE}

The purpose of this study is to answer the following three research questions:

1. What course structure would prospective students most prefer for completing online courses?

2. What skills do prospective online course students perceive as necessary for completing online courses?

3. What skills do prospective online course student perceive they possess for completing online courses?

\section{METHODOLOGY}

The methodology section includes a description of study participants, survey instrument, data collection procedures, and data analysis.

\section{Study Participants}

A convenience sample of 420 students enrolled in 11 sections of an information systems course served as the study participants. As required by Institutional Review Board approved protocol, participation was limited to those students who volunteered to partake in the study.

\section{Survey Instrument}

The survey instrument for this study was divided into three components: (1) preferred structure of online courses, (2) perceived skills needed to take online courses, and (3) perceived skills possessed to take online courses. These three components consisted of four, seven, and eight items, respectively. Student participant response options were yes/no for each item. Instrument face validity was determined by expert review. Face validity is simply expert opinion that the instrument is measuring what it is purported to measure [3]. Prospective online students provided input regarding both instrument content and clarity.

\section{Data Collection Procedures}

Data were collected from student participants enrolled in 11 sections of an information systems course who volunteered to participate in the study. Student participants accessed and completed the survey instrument 


\section{Issues in Information Systems \\ Volume 14, Issue 1, pp.415-420, 2013}

electronically via an "in-house" survey system. As per Institutional Review Board approved protocol, all responses were to remain anonymous through the removal of all identifiers prior to data analysis.

\section{Data Analysis}

Descriptive statistics were used to answer the three research questions. Specifically, the descriptive statistics of frequency and percentage were used to analyze the data and answer research questions one, two, and three.

\section{RESULTS}

The three research questions provide the framework for presenting study results.

\section{Research Question One}

Research question one sought to determine the preferred structure of online courses. Specifically, the four structures were: communication, deadlines, discussions, and participation in groups. The most preferred structured item was set deadlines for assignments, tests, and quizzes with 263 (63.7\%) of study participants selecting that item. The least preferred structured item was participation in groups with 120 (29.3\%) of study participants selecting that item. The number and percentage of students preferring each structure is presented in Table 1.

Table 1. Preferred Structure of Online Courses

\begin{tabular}{lcc}
\hline \multicolumn{1}{c}{ Preferred Structure } & $\begin{array}{c}\text { Number } \\
\text { Responding }\end{array}$ & Percentage \\
\hline No required communication with instructor & 180 & $43.8 \%$ \\
Required communication with instructor to keep on track & 231 & $56.2 \%$ \\
No set deadlines for assignments, tests, and/or quizzes & 150 & $36.3 \%$ \\
Structured deadlines for assignments, tests, and/or quizzes & 263 & $63.7 \%$ \\
& & $61.5 \%$ \\
No required student participation through discussion forums & 252 & $38.5 \%$ \\
Required student participation through discussion forums & 158 & $70.7 \%$ \\
& & $29.3 \%$ \\
No required participation with other students (i.e., group/team) & 290 & \\
Required participation with other students (i.e., group/team) & 120 &
\end{tabular}

\section{Research Question Two}

Research question two sought to determine perceived skills necessary for taking online courses. Specifically, the perceived skills were: computer/technology, reading, organization, self-discipline, time-management, and writing. The skill perceived as being most necessary for taking online courses was time-management with 377 (91.3\%) study participants selecting that item. The skill perceived as being the least necessary for taking online courses was writing with 127 (30.8\%) study participants selecting that item. The number and percentage of students preferring each structure is presented in Table 2.

\section{Research Question Three}

Research question three sought to determine the skills students perceived as possessed of taking online courses. Specifically, the perceived skills were: computer/technology, reading, organization, self-discipline, timemanagement, and writing. The skill perceived as being most possessed for taking online courses was reading with $333(80.6 \%)$ study participants selecting that item. The skill perceived as being the least possessed for taking online courses was computer/technology with 135 (32.7\%) study participants selecting that item. The number and percentage of students preferring each yes/no structure is presented in Table 3 . 
Table 2. Skills Perceived as Necessary for Taking Online Courses

\begin{tabular}{|c|c|c|c|}
\hline \multirow{2}{*}{\multicolumn{2}{|c|}{ Skills Necessary }} & \multicolumn{2}{|l|}{ Number } \\
\hline & & Responding & Percent \\
\hline \multirow[t]{2}{*}{ Writing } & Yes & 127 & $30.8 \%$ \\
\hline & No & 286 & $69.2 \%$ \\
\hline \multirow[t]{2}{*}{ Reading } & Yes & 351 & $85.0 \%$ \\
\hline & No & 62 & $15.0 \%$ \\
\hline \multirow[t]{2}{*}{ Self-discipline } & Yes & 375 & $90.8 \%$ \\
\hline & No & 38 & $9.2 \%$ \\
\hline \multirow[t]{2}{*}{ Organization } & Yes & 317 & $76.8 \%$ \\
\hline & No & 96 & $23.2 \%$ \\
\hline \multirow[t]{2}{*}{ Time management } & Yes & 377 & $91.3 \%$ \\
\hline & No & 36 & $8.7 \%$ \\
\hline \multirow[t]{2}{*}{ Computer/technology } & Yes & 352 & $85.2 \%$ \\
\hline & No & 61 & $14.8 \%$ \\
\hline
\end{tabular}

Table 3. Skills Perceived as Possessed for Taking Online Courses

\begin{tabular}{|c|c|c|c|}
\hline \multicolumn{2}{|c|}{ Skills Possessed } & \multirow{2}{*}{$\begin{array}{c}\begin{array}{c}\text { Number } \\
\text { Responding }\end{array} \\
290\end{array}$} & \multirow{2}{*}{$\begin{array}{l}\text { Percent } \\
70.2 \%\end{array}$} \\
\hline Writing & Yes & & \\
\hline & No & 123 & $29.8 \%$ \\
\hline \multirow[t]{2}{*}{ Reading } & Yes & 333 & $80.6 \%$ \\
\hline & No & 80 & $19.4 \%$ \\
\hline \multirow[t]{2}{*}{ Self-discipline } & Yes & 325 & $78.7 \%$ \\
\hline & No & 88 & $21.3 \%$ \\
\hline \multirow[t]{2}{*}{ Organization } & Yes & 324 & $78.5 \%$ \\
\hline & No & 89 & $21.5 \%$ \\
\hline \multirow[t]{2}{*}{ Time management } & Yes & 316 & $77.0 \%$ \\
\hline & No & 95 & $23.0 \%$ \\
\hline \multirow[t]{2}{*}{ Computer/technology } & Yes & 135 & $32.7 \%$ \\
\hline & No & 278 & $67.3 \%$ \\
\hline
\end{tabular}

\section{CONCLUSIONS}

The findings of this study are based on the results of 420 prospective online student participant responses at one midsized, Midwestern university who volunteer to participate in the study. As volunteer participants, the results of this study may not necessarily be representative of the greater student body. Thus, the following is put forward with that caution noted.

Structure is an important component of planning an online course. This study sought to determine the preferred online course structure of prospective online students. Interestingly, responses to the communication with the instructor online course structure item were about even with $56.2 \%$ wanting regular communication and $43.8 \%$ not wanting regular communication. Responses to the deadlines preferred online course structure indicated that $36.3 \%$ wanted deadlines and $63.7 \%$ did not want deadlines. Responses to the participation in discussion forum preferred online course structure indicated that $61.5 \%$ wanted no participation and $38.5 \%$ wanted participation. Responses to the participation with other students (i.e., group/team) preferred online course structure indicated that $70.7 \%$ did not want to participate with other students (i.e., group/team) and $29.3 \%$ wanted to participate with other students (i.e., group/team). There are interesting implications associated with prospective online student preferred course structure presented. In each case, the prospective online student preferred course structure is counter to the design of courses at the institution where this study was completed. For example, online course students are expected to engage in 


\section{Issues in Information Systems \\ Volume 14, Issue 1, pp.415-420, 2013}

regular communication with faculty, complete tasks by assigned deadlines, participate in discussion forums, and work in teams/groups with other students. Prospective online course students will need to be orientated to expectations before enrolling in such classes.

Skills perceived as necessary/possessed by prospective students for completing online courses successfully is also important. Interestingly, the skills perceived as necessary by perceptive online students of reading, self-discipline, organization, time management, and computer/technology skills were each rated as necessary by over $75 \%$ of study participants. The perceived skill of writing was rated as necessary by $30.8 \%$ of respondents. As for the skills perceived as possessed by prospective online course students, writing, reading, self-discipline, organization, and time management were listed as possessed by over $70 \%$ of study participants. The perceived possessed skill of computer/technology was perceived as possessed by $32.7 \%$ of study participants. Prospective online course student perceived as necessary and/or possessed most of the skills included in this study. Interestingly, only $32.7 \%$ prospective online course students reported possessing the needed computer/technology skills. This computer/technology skill disconnect as reported by prospective online course students was not expected. This computer/technology disconnect might be because prospective online course students do not fully understand the computer/technology skills needed by online course students. Prospective online course students might benefit from a computer/technology skills assessment and/or orientation before enrolling us such classes.

\section{ADDITIONAL RESEARCH RECOMMENDATIONS}

Based on the results of this study, and the review of the literature, the following additional research recommendations are offered:

1. It is recommended that this study be replicated with prospective online students at additional institutions. Such replications offer additional insight in the preferred student structure of online courses, perceived skills needed for completing online courses, and perceived skills possessed for completing online courses.

2. It is recommended that this study be expanded to include additional variables explored in other studies. Such a study would provide insight in the potential impact of these additional variables on prospective online students.

3. It is recommended that this study be replicated with prospective online students at the graduate level. The prospective online students in the current study current study were undergraduates. Such a study would provide insight into the preferred student structure of online courses, perceived skills needed for completing online courses, and perceived skills possessed for completing online courses of prospective graduate students.

\section{REFERENCES}

1. Aragon, S. R., \& Johnson, E. S. (2008). Factors influencing completion and noncompletion of community college online courses. The American Journal of Distance Education, 22, 146 - 158.

2. Doherty, W. (2006). An analysis of multiple factors affecting retention in Web-based community college courses. Internet and Higher Education, 9, 245 - 255.

3. Galy, E., Downey, C., \& Johnson, J. (2011). The effect of using e-learning tools in online and campus-based classrooms on student performance. Journal of Information Technology Education, 10, 209 - 230.

4. Gay, L. R., Mills, G. E., \& Airasian, P. (2012). Educational research: Competencies for analysis and applications. Upper Saddle River, NJ: Pearson Education.

5. Harrell, II, I. L., \& Bower, B. L. (2011). Student characteristics that predict persistence in community college online courses. The American Journal of Distance Education, 25, 178 - 191.

6. Holsapple, C. W., \& Lee-Post, A. (2006). Defining, assessing, and promoting e-learning success: An information systems perspective. Decision Sciences Journal of Innovative Education, 4(1), 67 - 85.

7. Hung, M. L., Chou, C., Chen, C. H., \& Own, Z. Y. (2010). Learner readiness for online learning: Scale development and student perceptions. Computers \& Education, 55, $1080-1090$.

8. Kerr, M. S., Rynerson, K., \& Kerr, M. C. (2006). Student characteristics for online learning success. Internet and Higher Education, 9, 91 - 105.

9. Levy, Y. (2007). Comparing dropouts and persistence in e-learning courses. Computers \& Education, 48, $185-$ 204. 


\section{Issues in Information Systems \\ Volume 14, Issue 1, pp.415-420, 2013}

10. Morris, L. V., Finnegan, C., \& Wu, S. (2005). Tracking student behavior, persistence, and achievement in online courses. Internet and Higher Education, 8, $221-231$.

11. Wojciechowski, A., \& Palmer, L. B. (2005). Individual student characteristics: Can any be predictors of success in online classes? Online Journal of Distance Learning Administration, 8(2), retrieved from http://www.westga.edu/ distance/ojdla/summer82/wojciechowski82.htm on April 30, 2013. 